\title{
TALKING WITH THE EMPEROR: DIPLOMACY AND LANGUAGE BETWEEN GREECE AND ROME*
}

A prominent feature of the dynamics between Rome and the Greek territories is represented by the extensive use of the imperial figure as a political and ideological instrument. The epigraphic sources underline how the Greek cities offered rites and honours to the emperor who was currently in power, employing them as a key element and the perfect prop to ensure the emperor's approval. ${ }^{1}$ Moreover, in their attempts to gain the emperor's favour, cities, leagues, and synods tended to employ a characteristic language that remained broadly unchanged from early Imperial times to the end of the second century AD.

The purpose of the following discussion is to analyse the recurring pattern that cities, koina (leagues of cities), and Greek synods followed in their dealings with the emperor, together with the language employed by both sides. The epigraphic evidence of the imperial replies typically points to a series of steps which would have included at least: the honours bestowed on the emperor; an embassy to the emperor; and the imperial ratification. In the second part of the article this pattern will be used as a model in order to shed some light on the kind of

\footnotetext{
* I wish to thank Professor G. D. Woolf for his invaluable advice and the project 'Adriano y la integración de la diversidad regional. Una perspectiva histórica e historiográfica' (HAR201565451-C2-1-P), 01/01/2016-31/12/2018, of the Universidad Pablo de Olavide. All translations are from J. H. Oliver, Greek Constitutions of Early Roman Emperors from Inscriptions and Papyri (Philadelphia, PA, 1989), unless otherwise specified.

${ }^{1}$ On the diplomacy in Rome, see R. J. A. Talbert, The Senate of Imperial Rome (Princeton, NJ, 1984), 411-25; F. Millar, 'Government and Diplomacy in the Roman Empire during the First Three Centuries', International History Review 10.3 (1988), 345-77; J. Linderski, 'Ambassadors Go to Rome', in E. Frézouls and A. Jacquemin (eds.), Les Relations internationales. Actes du colloque de Strasbourg, 15-17 juin 1993 (Paris, 1995), 453-78; F. Millar, Rome, the Greek World, and the East 2. Government, Society $\mathcal{E}$ Culture in the Roman Empire (Chapel Hill, NC, 2004), 375-85, 410-20; W. Eck, 'Diplomacy as Part of the Administrative Process in the Roman Empire', in C. Eilers (ed.), Diplomats and Diplomacy in the Roman World (Leiden and Boston, MA, 2009), 193-208; B. Gibson, 'The Representation of Greek Diplomacy in Tacitus', in J. M. Madsen and R. Rees (eds.), Roman Rule in Greek and Latin Writing. Double Vision (Leiden and Boston, MA, 2014), 124-43; A. Chaniotis, 'Affective Diplomacy: Emotional Scripts between Greek Communities and Roman Authorities during the Republic', in D. Cairns and L. Fulkerson (eds.), Emotions between Greece and Rome (London, 2015), 87-103.
} 
negotiations which might have taken place between the emperor and the future members of the Panhellenion.

\section{Honours awarded to the emperor ${ }^{2}$}

The available epigraphic evidence mainly consists of the emperors' replies to those cities, synods, and koina who had sent embassies to the imperial court in order to gain the emperor's favour. All of the inscriptions show that the first step of the diplomatic process was to inform the emperor of the honours which the cities, synods, or koina had approved to dedicate to him. Such honours bestowed on the emperor ranged, to name a few, from the erection of statues, through the construction or dedication of temples complete with a college of priests appointed to carry out the rituals, to the creation of new agones (athletic and/or musical contests). The most detailed example of this is found in an inscription where the Council of the Areopagus, the Council of the Five Hundred, and the Demos of the Athenians decided

to offer sacrifices in every family and to keep holiday both publicly and privately for all the imperial family; to celebrate this dies imperii in accord with their other dies imperii [as] we have learned through their holy announcement and to give a distribution [to the whole populace]

$\left(I G \mathrm{II}^{2}, 1077\right)^{3}$

on the occasion of the joint rule of Caracalla and Geta.

The imperial replies show that, even after the honours had been approved by cities or leagues, the emperor's ratification was necessary in order for them to be carried out. From Tiberius' letter to the Gytheates it emerges how the city showed to the emperor its plan to organize a thymelic contest and grant cult honours to Augustus, Livia, and Tiberius himself. The emperor replied by ratifying the honours for Augustus but turning down those dedicated to himself: 'I consider it proper...to maintain exceptional honors which are due to gods for the great benefactions of my father to all the world, but I myself am content with the more moderate honors which are proper for men.' ${ }^{4}$ In

${ }^{2}$ E. Guerber, Les Cités grecques dans l'Empire romain. Les Privilèges et les titres des cités de l'orient hellénophone d'Octave Auguste à Dioclétien (Rennes, 2009), 215-301.

${ }^{3}$ Translation from J. H. Oliver, Marcus Aurelius. Aspects of the Civic and Cultural Policy in the East, Hesperia Supplement 13 (Princeton, NJ, 1970), 111.

${ }^{4}$ J. H. Oliver, Greek Constitutions of Early Roman Emperors from Inscriptions and Papyri (Philadelphia, PA, 1989), no. 15. 
Claudius' letter to the Alexandrians, the emperor expresses his approval by simply stating 'I have gladly received the honors you have given me.' Apart from turning down or ratifying the honours offered by the cities, the emperors also sometimes made suggestions about them. An example of this is represented by Marcus Aurelius and Commodus' letter to the Athenian gerusia (council of elders), where the emperors replied to the gerusia's offer to make a portrait of an unspecified material (probably gold or silver) by saying 'be willing to [content] yourselves with bronze [portraits]'. 6 The inscriptions mentioning the honours organized by the synods show the same pattern as those involving the cities. $^{7}$ The 'Dionysiac Artists of the Habitable World, Sacred Victors Entitled to Crowns and their Fellow Contestants' sent an embassy to Emperor Claudius in order to tell him of their plan to erect a number of statues in his honour, with the emperor replying 'as for the statues, I allow you to erect them in the way for us to be piously revered with the proper honor'. ${ }^{8}$

Among the documents relating the honours awarded by the koina, there is an inscription which shows the reply of Emperor Caligula to a petition sent by the koinon of the Achaeans, Boeotians, Locrians, Phocians, and Euboeans, in which the emperor ratifies the league and also mentions the honours that had been bestowed on him by the league (surely in order to ensure the ratification of the petition):

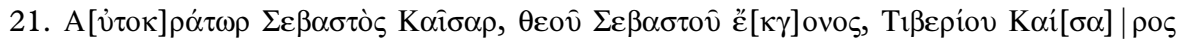

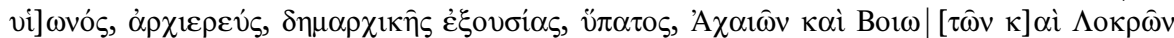

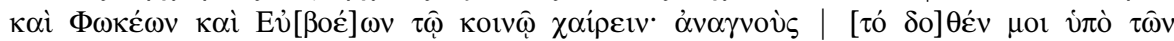

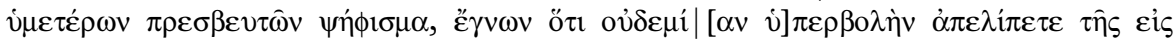

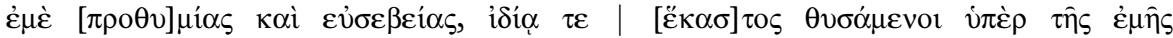

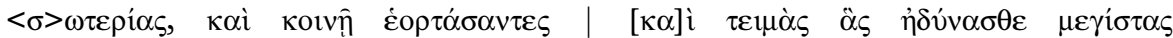

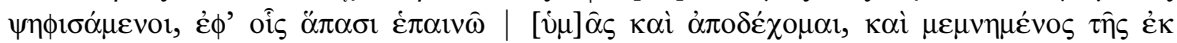

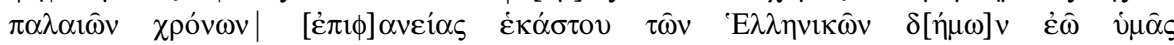

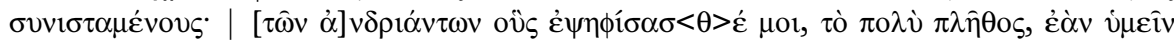

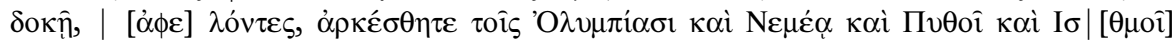
$\tau \varepsilon \theta \eta \sigma o \mu \varepsilon ́ v o r \varsigma^{9}$

${ }^{5}$ P. Lond. 1912, line 28. Translation from Oliver (n. 4), no. 19.

${ }^{6}$ Oliver (n. 4), no. 196, line 58.

${ }^{7}$ C. Habicht, 'Zum Gesandtschaftsverkehr griechischer Gemeinden mit römischen Instanzen während der Kaiserzeit', Archaiognosia 11 (2001-2), 11-28, esp. 18.

${ }^{8}$ POxy. 2476.

${ }^{9} I G$ VII, no. 2711, lines 21-33. 
Imperator Augustus Caesar, descendant of divus Augustus, grandson of Tiberius Caesar, pontifex maximus, tribunician power, consul, to the Commonalty of the Achaeans and Boeotians and Locrians and Phocians and Euobeans, greetings.

Upon reading the decree given to me by your ambassadors I recognized that you displayed an unsurpassable [zeal] and devotion to me, sacrificing individually for my security and as a group celebrating and decreeing the greatest honours you could. I both praise you for all this and accept with approval. And remembering the distinction from ancient times of each of the Greek republics, I allow your union. As for the statues which you voted me, if you please, reduce the great number and be content with those that will be placed at Olympia and Nemea and at the Pythian sanctuary and at the Isthmus. ${ }^{10}$

The emperor praises the honours that had been bestowed on his person, which include the ceremonies and most of all the statues dedicated to him. The dedication of statues appears to have been one of the main elements through which koina and cities endeavoured to ensure the emperor's approval of the petitions sent to him. In the case of Caligula's inscription, the emperor humbly says to reduce the number of the statues that the new league wished to set up in his honour to the ones to be erected in the sanctuaries of Olympia, Nemea, Delphi, and Isthmia. This approach is also found in a letter sent by Hadrian to the same koinon, in this case referred to as 'the Commonalty of the Achaeans', where the emperor turns down a series of honours, the details of which remain unknown owing to the poor state of the stele. ${ }^{11}$

\section{Embassy to the emperor and the language of the emperor's replies}

To varying degrees, the epigraphic sources imply the sending of a delegation, on behalf of the person or institution in charge of celebrating the honours, to present the emperor with the honours awarded to him, often together with some kind of request. Typically, the envoys who were sent to the emperor belonged to the city elites, since they could afford the costs of travel and were skilled orators, so that they could try to persuade the emperor to accept their requests, should he appear doubtful. ${ }^{12}$ Many of them are known to us through the official

${ }^{10}$ Translation from Oliver (n. 4), no. 18.

${ }^{11} I G \mathrm{II}^{2}$, no. 1094 .

${ }^{12}$ It was customary to choose physicians and sophists as city representatives: see G. W. Bowersock, Greek Sophists in the Roman Empire (Oxford 1969), 33-43; E. L. Bowie, 'The Importance of Sophists', YClS 27 (1982), 29-59; F. Quass, Die Honorationenschicht in den 
responses sent by the emperor, since at the beginning or end of the proceedings there is usually mention of the envoys as bearers and witnesses of the imperial response. ${ }^{13}$ The previously mentioned ratification of the petition from the koinon of the Achaeans, Boeotians, Locrians, Phocians, and Euboeans by Caligula attests that the emperor took his decision after having read the decree that the envoys had brought to him. Among the members of the legations are the Chief Ambassador, whose name has not been preserved; Timoxenus, son of Timoxenus; Menophanes; Epaminondas, son of Epaminondas; and Heraclitus, son of Olympion. ${ }^{14}$

Werner Eck, in his work on diplomacy, states that 'countless documents show that the purpose of these embassies, at least according to external appearances, was ceremonial' ${ }^{15}$ Similarly, Fergus Millar states that the embassies had as their main goal to show to the emperor the loyalty of the cities, synods, or koina. ${ }^{16}$ Marcus Aurelius and Antoninus Pius' letter to the Dionysiac Society at Smyrna mentions the synod's 'goodwill' ( $\varepsilon$ vvoro) for the news of the birth of a new member of the imperial family (who unfortunately did not survive): 'The goodwill which you displayed in rejoicing at the birth of a son to me'. ${ }^{17}$ The term Eüvor $\alpha$ also appears in Avidius Cassius' letter to the Alexandrians referring to the city taking Avidius' side: 'bearing [in] your hearts that goodwill toward me'. ${ }^{18}$ Among the deeds that the cities celebrate is the proclamation of a new heir to the imperial power. A letter by Septimius Severus to the Aezanitae mentions the missive previously sent by the city to the emperor in order to celebrate the emperor's choice of his heir: 'The pleasure which you take in our success and in the rise of my son M. Aurelius Antoninus with good fortune

Städten des griechischen Ostens. Untersuchungen zur politischen und sozialen Entwicklung in hellenistischer und Römischer Zeit (Stuttgart, 1993), 152-6; S. Mitchell, 'The Administration of Roman Asia from 133 BC to AD 250', in W. Eck and E. Müller-Lucker (eds.), Lokale Autonomie und römische Ordnungsmacht in den kaiserzeitlichen Provinzen vom 1. bis 3. Fahrhundert (Munich, 1999), 45; Habicht (n. 7), 17-19.

${ }_{13}$ Oliver (n. 4), nos. 18, 23, 24, 39, 213.

${ }^{14}$ IG VII, no. 2711, lines 21-42.

${ }^{15}$ Eck (n. 1), 195.

${ }^{16}$ Millar (n. 1), 410-20.

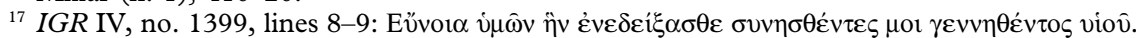
Translation from Oliver (n. 4), 326.

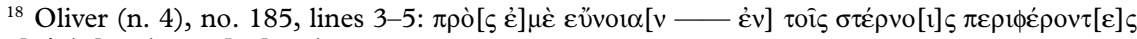

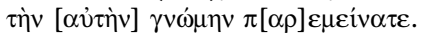


to hopes of becoming emperor and in the appointment he has received beside his father'. ${ }^{19}$

The cities usually employed this kind of language mainly in order to curry the emperor's favour, given that the embassies, apart from shows of goodwill and announcements of honours, also included all kinds of petitions for the emperor to grant. For example, in the previously mentioned letter by Caligula to the koinon of the Achaeans, the emperor allows for the erection of statues in the Panhellenic sanctuaries of Olympia, Nemea, Delphi, and Isthmus, but he also ratifies the creation of the Achaean League. In the inscription, Caligula refers to the enthusiasm and devotion shown by the league in its embassy to the emperor: 'I recognized that you displayed an unsurpassable [zeal] and devotion to me'. ${ }^{20}$

The inscriptions also show how the cities' embassies typically mention their loyalty to the emperor in order to gain concessions and privileges. One of the clearest examples of this is Augustus' letter to the Samians, in which the Samians ask the emperor to make them free, since he did the same to the citizens of Aphrodisias. Augustus states in his reply that only the cities that remained on Augustus' side during his conflict with Mark Anthony are allowed to ask for this privilege: 'freedom to no demos except to that of the Aphrodisians, who, having taken my side in the war, suffered capture on account of their loyalty to us'. ${ }^{21}$ Loyalty is also mentioned in Tiberius' letter to the Aezanitae, where the emperor shows the city his favourable disposition because of 'the loyalty and sympathy you had for me'. ${ }^{22}$ In the previously mentioned letter by Claudius to the Alexandrians, the emperor mentions the loyalty expressed by the city in its embassy: 'for you are by disposition loyal to the Augusti' ${ }^{23}$ Trajan's letter to the Alexandrians also refers to Alexandria's loyalty towards the emperor, in the passage

${ }^{19}$ Tìv $\dot{\eta} \delta$ ovìv

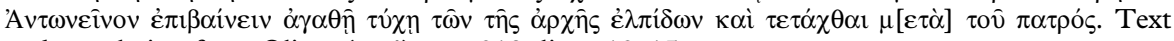
and translation from Oliver (n. 4), no. 213, lines 12-15.

${ }^{20}$ Oliver (n. 4), no. 18, lines 24-25.

${ }^{21}$ J. Reynolds, Aphrodisias and Rome (London, 1982), no. 13, lines 2-3. Translation from Oliver (n. 4), 25.

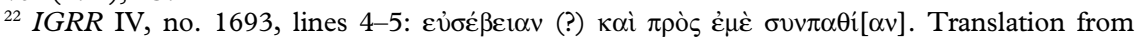
Oliver (n. 4), 56.

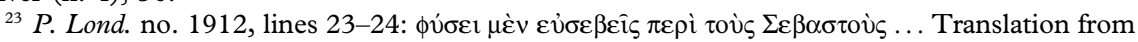
Oliver (n. 4), 81. 
'[Appreciating] your city's extraordinary [loyalty] to the Augusti'. ${ }^{24}$ Similarly, in Marcus Aurelius and Lucius Verus' letter to the Beroeans, the emperors consider the city's loyalty as a valid reason for granting the privileges it asks: 'Inasmuch as you [loyally show] joy in [your decree]'. ${ }^{25}$ The mention of loyalty remained common during later times, as in Septimius Severus' letter to the Aphrodisians: '[by] decree, so that we might know your pious loyalty'. ${ }^{26}$

Apart from asking the emperor for privileges, the cities also used the embassies in order to request that the emperor ratify the privileges previously granted by previous emperors. ${ }^{27}$ In Claudius' letter to the Thasians, the emperor approves the erection of a temple for the imperial cult which the city had asked him to authorize in consideration of the its loyalty: 'I approved the [verbal expressions] of [your] zeal and loyalty in their entirety', ${ }^{28}$ and also fulfils the city's request to ratify the privileges already granted by Augustus: 'I preserve for you according to the [decisions] of [the deified] Augustus all the privileges you received from him in reference to what you previously had and especially to the export of grain' ${ }^{29}$ In Hadrian's letter to Delphi, the emperor refers to the city's displays of loyalty and agrees to ratify the autonomy that had been granted to it by the previous emperors:

[because] the antiquity and nobility of the city are well known to me from far back, and not least because [you made your zeal for me] clear [when you were congratulating me] upon [my] succession [to the ancestral office] and were calling upon the god [to grant me the] blessings. [Therefore I guarantee the] freedom and autonomy [of your city] as well as the gifts [from the emperors who preceded me, just as they were maintained] also by [my father], the [divine Trajan]. ${ }^{30}$

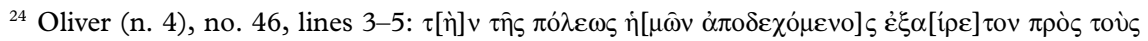

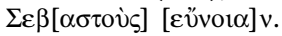

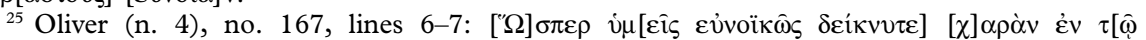
$\psi \eta \phi i ́ \sigma \mu \alpha \tau \imath]$.

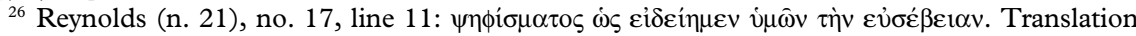
from Oliver (n. 4), 442.

${ }_{27}$ POxy. no. 2476; P. Lond. no. 1178; P. Würz. 9; FD 3.4, nos. 311-13; Oliver (n. 4), nos. 20, 23, 29, 44, 113, 117-18, 215, 218; Reynolds (n. 21), no. 15.

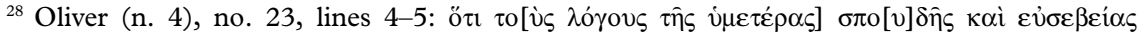

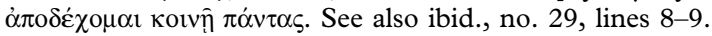

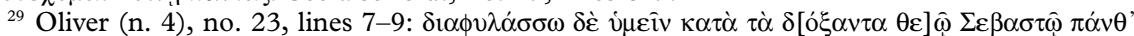

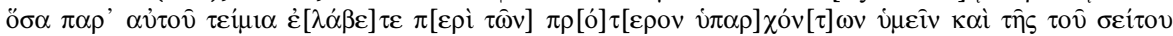
$\dot{\varepsilon} \xi \alpha \gamma \omega \gamma \hat{\eta} \varsigma$.

${ }^{30} F D$ 3.4, no. 301, lines 5-10. Translation from Oliver (n. 4), 158. 


\section{Imperial ratification}

The analysis of the language of the imperial ratifications of the cities' petitions depicts the imperial figure as caring, protective, and willing to help his subjects. In Tiberius' letter to the Coans, the emperor states: 'I was [well] disposed [toward] your [city] even previously'. ${ }^{31}$ The same kind of language is found in Nero's letter to the Rhodians ('I for my part have been well disposed toward you from my earliest years' ${ }^{\prime 32}$ ), Claudius' letter to the Delphians ('For a long while [I have been] not only [well disposed] toward the city of the Delphians [but unwavering in my friendship]'33) and the same emperor's to the Alexandrians ('I for my part will care for the city as much as I can, as one which has long been closely connected with us ${ }^{34}$ ). Furthermore, in one of Hadrian's replies, the emperor explicitly states that he is helping the Greek cities with their funding: 'I myself, cooperating with the cities toward a good supply of funds'. ${ }^{35}$ Hadrian's involvement with the Greek world is also highlighted by the help he gives to the synod of the technitai (artists). In the third letter of the stele in the Alexandria Troad, the emperor grants to the synod the anaptosis (a banquet given in honour of the winners of the agones), saying that he is doing it in accordance with my own custom'. ${ }^{36}$

There is also the issue of whether the honours related to the cult of the emperor needed not only the imperial approval but also that of the Senate. An example of this is represented by the dispute over which city would erect

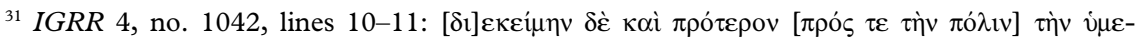
[ $\tau \dot{\varepsilon} \rho \alpha v]$. Translation from Oliver (n. 4), 57.

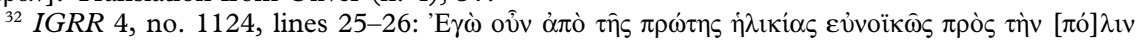

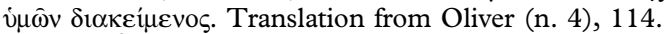

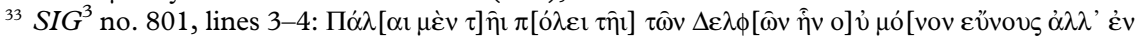

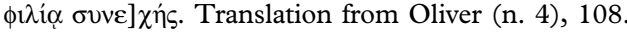

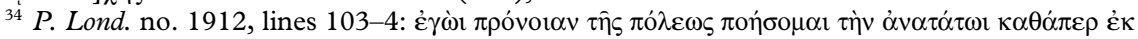

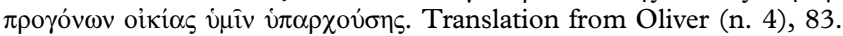

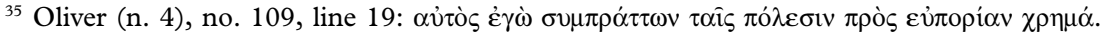

${ }^{36}$ G. Petzl and E. Schwertheim, Hadrian und die dionysischen Künstler. Drei in Alexandria Troas

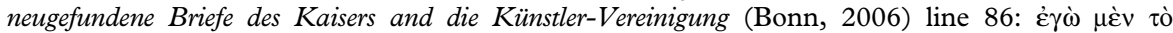

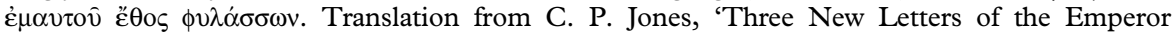
Hadrian', ZPE 161 (2007), 145-56, esp. 156. As the synod's benefactor, Hadrian granted it 'the inviolability, right to front seats, freeedom from military service, immunity from public liturgies, the right not to present guarantors of their immunity from taxation, the right to meet together for sacrifice, the right not to be compelled to accommodate strangers with billets, freedom from imprisonment or any other form of detention' and also 'a place where you wish I shall order to be given to you and a building to house your archive'. Oliver (n. 4), no. 86 and no. 96 A-C. 
a temple to Tiberius, Livia, and the Senate in Asia: according to Tacitus' account, the emperor attended the senatorial debates between the different cities that wished to host the temple. ${ }^{37}$ The Senate was not entirely left out of the decisions taken by the emperor in religious matters when it came to Roman cults, and it formally endorsed what the emperor had decided, as we can see in the titulatures in which the cities that had obtained a neokoria (the title bestowed on a city with a temple for the imperial cult) would have the right to display their new privilege, which appears to have been granted by 'decree of the Senate'. ${ }^{38}$ In Hadrian's letter to the Aphrodisians concerning the immunity from the tax on nails, the emperor ratifies their freedom and autonomy as well as the other rights: 'Your freedom and autonomy as well as the other rights recognized in your case by the Senate'. ${ }^{39}$ In the same emperor's second letter to the travelling musical union of artists associated with Dionysus, he creates a nea periodos, a fouryear agonistic calendar that includes those games that have been 'authorized by the most eminent Senate'. ${ }^{40}$

\section{A case study: the Panhellenion League}

If we accept as valid the previously mentioned hypothesis of the existence of a consistent pattern that was followed by the dialogue between emperors and cities, koina, or synods, it might be possible to infer more information about the creation of some new political structures in Roman Greece. One of the most problematic cases is that of the Panhellenion League, which was founded during Hadrian's rule. The lack of archaeological and epigraphic evidence does not allow the provision of a definitive answer to many of the issues related to the Panhellenion, including the process of creation of the league itself. Nevertheless, a plausible reconstruction of the kind of dialogue and negotiations which took place between the future members of the Panhellenion and the emperor Hadrian might be fleshed out by using as a framework the diplomatic process described below.

37 Tac. Ann. 4.55.

${ }^{38}$ S. Price, Rituals and Power. The Roman Imperial Cult in Asia Minor (Cambridge, 1984) 66-7; B. Burrell, Neokoroi. Greek Cities and Roman Emperors (Leiden and Boston, MA, 2004).

${ }^{39}$ Reynolds (n. 21), no. 15, lines 5-8. Translation from Oliver (n. 4), 167.

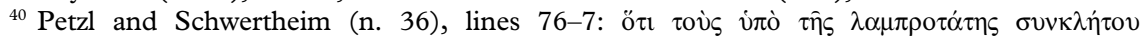

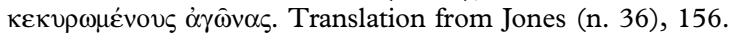




\section{Honours bestowed on the emperor}

Hadrian was known to the Athenians before his rise to power. As a philhellenic emperor, he had spent much time in the city studying the Greek language and partaking in the Greek culture, as demonstrated by his initiation into the Eleusinian mysteries. ${ }^{41}$ Because of its philo-Athenian position, inscriptions throughout the city of Athens link him to Zeus Eleutherios ${ }^{42}$ and present him as the new ktistes (founder) of the city, the new Theseus. ${ }^{43}$ Hadrian also funded the construction of numerous buildings, such as the library, the gymnasium, the aqueduct, and the new Athenian district. ${ }^{44}$ Among the many projects that he funded, however, there is one that stands out: the Olympieion: the erection of the temple of Zeus Olympios was completed thanks to the emperor covering the costs, which is the reason why, from $129 \mathrm{AD}$, he would be called 'Olympios'. ${ }^{45}$

The grand inauguration of the temple of Zeus Olympios in Athens took place on the banks of the Ilissos and was presided over by Hadrian himself. ${ }^{46}$ This ceremony marked an important moment in the history of the Panhellenion, with the emperor surrounded by an

${ }^{41}$ On the relationship of Hadrian and Eleusis, see R. Gordillo, 'La rehabilitación de las Aparchai en época imperial', Antigüedad: Religiones y Sociedades 9 (2011), 177-90. See also K. Clinton, Eleusis. The Inscriptions on Stone. Documents of the Sanctuary of the Two Goddesses and Public Documents of the Deme (Athens, 2005), no. 489.

${ }^{42}$ In the theatre of Dionysus there was a seat reserved for the priest of Hadrian Eleutherios: $I G$ $\mathrm{II}^{2}$, 5035; K. W. Arafat, Pausanias' Greece. Ancient Artists and Roman Rulers (Cambridge, 1996), 163; A. Karivieri, 'Just One of the Boys: Hadrian in the Company of Zeus, Dionysus and Theseus', in E. N. Ostenfeld (ed.), Greek Romans and Roman Greeks (Aarhus, 2002). Another theory suggests that the relationship between the deity and the emperor is only one of affiliation: A. Raubitschek, 'Hadrian as the Son of Zeus Eleutherios', AfA 49.2 (1945), 128-33.

${ }^{43} \mathrm{On}$ the arch of Hadrian in Athens the emperor is linked directly to Theseus: $I G \mathrm{II}^{2}, 5185 \mathrm{AB}$. On this arch, see J. Travlos, Pictorial Dictionary of Ancient Athens (New York, 1971), 253-7; A. Adams, 'The Arch of Hadrian at Athens', in S. Walker and A. Cameron (eds.), The Greek Renaissance in the Roman Empire. Papers from the Tenth British Museum Classical Colloquium (London, 1989), 10-15; D. Willers, Hadrians panhellenisches Programm. Archäologische Beiträge zur Neugestaltung Athens durch Hadrian (Basel, 1990), 72-85.

${ }^{44}$ On the emperor's euergesiai (monetary contribution) in Athens, see M. T. Boatwright, Hadrian and the Cities of the Roman Empire (Princeton, NJ, 2000); E. Calandra, Oltre Grecia. Alle origini del filellenismo di Adriano (Perugia, 1993); R. Gordillo, La construcción religiosa de la Hélade imperial. El Panhelenion (Florence, 2012).

${ }^{45}$ On the funding of the works for the completion of the temple by the emperor, see St. Byz. Olympieion. On the dating of the introduction of the term 'Olympios' within the emperor's titulature, see W. E. Metcalf, 'Hadrian, Iovis Olympius', Mnemosyne 27.1 (1974), 59-66.

${ }^{46}$ On the Olympieion, see Travlos (n. 43), 402-11; Willers (n. 43); Calandra (n. 44), 89-91; Boatwright (n. 44), 69-71; E. Greco, Topografia di Atene. Sviluppo urbano e monumenti dalle origini al III secolo d.C. Tomo 2, Colline sud-occidentali-Valle del'Ilisso (Athens, 2011), 369-95. 
enormous number of Greeks from every part of the Hellenic world. ${ }^{47}$ The city of Athens was flooded with offerings drawn from many Greek cities in the provinces of Achaia and Asia. According to Pausanias, a large number of bronze statues of the emperor, which depicted him as ktistes, evergetes (benefactor), and soter (saviour) of those same cities that had sent the statues to Athens, were erected in the grounds of the Olympieion. These statues, called koloniai by Pausanias, were displayed under the colossal statue that the Athenians had erected behind the temple in honour of the emperor. ${ }^{48}$

\section{Embassy to the emperor}

No extant source provides evidence that some or all of the cities that would become members of the Panhellenion sent an embassy to Hadrian, and therefore we cannot prove their initiative in the creation of a Panhellenic league, although, of course, the absence of such evidence is not enough to rule out the possibility of a Greek embassy to Rome. But the arrival of the emperor in Athens for the inauguration of the Olympieion was surely seen by all the Greeks as a chance to show their loyalty and devotion, and also to approach him directly and without incurring great expense, as embassies to the emperor usually had to travel to Rome itself. Thus, although there is no direct evidence for this, it could be hypothesized that the inauguration of the Olympieion was exploited by the various cities in order to present to the emperor their proposal for forming a league. In this case, the koloniai would be nothing more than each city's means of individually expressing their loyalty to the emperor and ensuring his approval for the creation of the league. Hadrian would have found it opportune to ratify their proposal, since the creation of such a league would have been a valuable political tool. Alternatively, it could be hypothesized that, following the failure of the Amphictiony of Delphi, Hadrian was

${ }^{47} I G \mathrm{IV}$, no. $1052=I G \mathrm{IV}^{2} 1$, no. 384.

${ }^{48}$ Paus. 1.18.6. Today only some of the bases of the colonies remain: Abydos: $I G \mathrm{II}^{2}$, no. 3290; Anemurio: $I G \mathrm{II}^{2}$, no. 3293; Amphipolis: $I G \mathrm{II}^{2}$, no. 3292; Antioch (Pisidia), CIL III, no. 7283; Cerami: $I G \mathrm{II}^{2}$, no. 3306; Cipro Kotvóv: $I G \mathrm{II}^{2}$, no. 3296; Cyzicus: $I G \mathrm{II}^{2}$, no. 3294; Alexandria (Troas): CIL III, no. 7282; Coropissus: $I G \mathrm{II}^{2}$, no. 3307; Dion: $I G \mathrm{II}^{2}$, no. 3289; Ephesus: $I G \mathrm{II}^{2}$, no. 3297; Aegina: $I G \mathrm{II}^{2}$, no. 3291; Laodicea ad Mare (Syria): $I G \mathrm{II}^{2}$, no. 3299; Magnesia on the Maeander: $I G \mathrm{II}^{2}$, no. 3305; Miletus: $I G \mathrm{II}^{2}$, no. 3300; Pale (Cephalonia): $I G \mathrm{II}^{2}$, no. 3301; Pompeiopolis (Cilicia): $I G \mathrm{II}^{2}$, no. 3302; Pompeiopolis (Bithynia): $I G \mathrm{II}^{2}$, no. 3298; Sebastopolis (Ponto): $I G \mathrm{II}^{2}$, no. 3303; Sesto: $I G \mathrm{II}^{2}$, no. 3304; Taso: $I G \mathrm{II}^{2}$, no. 3295; Philadelphia in Lydia: SEG 41, no. 143. 
still looking for a way to establish a supranational Panhellenic league. Therefore, the emperor would have exploited the inauguration of the Olympieion and being honoured as ktistes by the cities of the provinces of Achaia and Asia in order to create a league of Greek cities under the aegis of Zeus Olympios.

This second step, either in the form of an embassy or through more direct contact, while not unequivocally clarified by the extant sources when it comes to the creation of the Panhellenion, was a constant feature of the ratification of the privileges of cities and koina. The reason why no source mentions the sending of a missive to Hadrian in order to inform him of the honours he had received would be that such an embassy was not necessary, since he was witnessing the ceremonies from the peribolos of the Olympieion (the temple's enclosed court) in person.

\section{Imperial ratification}

The imperial ratification of the Greeks' request for the creation of the Panhellenion and Hadrian's promotion of the foundation of the league in Athens are bound to be regarded as mutually exclusive. The leagues had to be associated with a deity who would act as their protector; the Panhellenion temple was probably dedicated to Zeus Panhellenios and was the centre of the imperial cult of the promoter of the league, who was worshipped as Hadrian Panhellenios or as Hadrian Olympios Panhellenios. ${ }^{49}$ The epigraphic and literary sources demonstrate that the imperial cult was one of the instruments most commonly utilized by the cities and leagues to approach the emperor. Not all the petitions addressed to the emperor were successful, especially those concerning the creation of an imperial cult, which required not only the building of a temple but also the creation of a body of priests appointed to the rituals, which the emperors were not keen on accepting so that they would not appear to be guilty of hubris. ${ }^{50}$ In the case of the

${ }^{49}$ For Hadrian Panhellenios, see $I G \mathrm{II}^{2}$, nos. 3626 and 3386; P. Weiss, 'Eumeneia und das Panhellenion', Chiron 30 (2000), 617-39, no. 21617-639 and no. 21. For Hadrian Olimpios Panhellenios, see IGR IV, no. 552; IGR IV, no. 1157; BM 1907, nos. 1, 5, 6.

${ }^{50}$ The emperor could reject certain kind of honours: see M. P. Charlesworth, 'The Refusal of Divine Honours: An Augustan Formula', PBSR 15 (1939), 1-10; C. Habicht, 'Die augusteische Zeit und das erste Jahrhundert nach Christi Geburt', in W. Boer and E. J. Bickerman (eds.), Le Culte des souverains dans l'Empire romain (Geneva, 1973), 41-99. For the cases of Tiberius' refusal to the Hispanici who wanted to build a temple in his honour, of Claudius to the Alexandrians or Nero to the Arsinoites, see Tac. Ann. 4.37.2-4.38.44 (Tiberius); Oliver (n. 4), no. 19 (Claudius); ibid., no. 39 (Nero). 
Panhellenion, however, we have Dio Cassius clearly stating that the rituals were approved by Hadrian. Thus, the Greeks were allowed to carry out the construction of the temple called the Panhellenion in Athens and to organize the Panhellenic games dedicated to the temple deity (also in Athens), ${ }^{51}$ the funding of which was supervised by the archon of the assembly of the Panhellenion. ${ }^{52}$ Hadrian's favour towards Athens is well exemplified by an inscription where he states ' $k$ now that I take every occasion to benefit both the city publicly and any of the Athenians privately'. ${ }^{53}$

The dynamics between the emperor and the elites of the Greek cities show Hadrian playing the role of the promoter and protector of the Panhellenic ideal. As we can see from the inscription of Thyatira, the emperor appears to have brought the proposal before the Senate, since 'following his proposal, [the Romans] approved the venerable

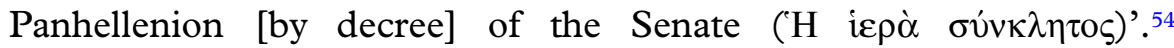
Nevertheless, because the cult of the emperor related to the Panhellenion, as a non-Roman cult it would not have come under the religious oversight of the Senate and it is unlikely that the senatorial approval mentioned in the Thyatira inscription would have been a decisive factor.

\section{Conclusion}

The inscriptions which relate the dialogue between the emperor and the Greek cities, koina, and synods allow us to trace a pattern that remains broadly unchanged for at least two centuries: first, honours awarded to the emperor; then an embassy to the emperor; and, finally, imperial ratification. From what can be inferred from epigraphic evidence, the embassies to the emperor employed a consistently flattering language

\footnotetext{
${ }^{51}$ On the Panhellenic agones, see: Oliver (n. 4), nos. 9 and 19; $I G \mathrm{II}^{2}$, no. 1093; $I G \mathrm{II}^{2}$, no. 2243; $I G \mathrm{II}^{2}$, no. 3626; IG IV, no. 1474; IG X.2, no. 181; IGR IV, nos. 573 and 576; Philostr. V $S 2.1 .3$ and 2.17 .

${ }_{52}$ On the priesthood of Hadrian Panhellenios, see $I G \mathrm{II}^{2}$, nos. 1093 and 3626; IG IV, nos. 1474; IGR IV, nos. 573 and 576; Oliver (n. 4), no. 36.

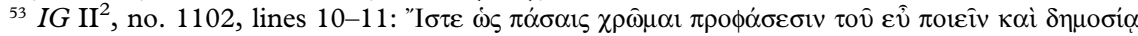

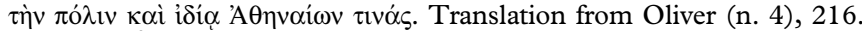

${ }^{54} I G \mathrm{II}^{2}$, nos. 1088-90, line 17. This ought to take into account the many frictions that had existed between the Senate and Hadrian since his first years of office. On the relationship between the Senate and the Panhellenion, see V. Marotta, 'Il Senato e il Panhellenion', Ostraka 4.1 (1995), 157-67; S. Follet and D. Peppas Delmousou, 'Le Décret de Thyatire sur les bienfaits d'Hadrien et le "Panthéon" d'Hadrien', BCH 121.1 (1997), 291-309, esp. 302.
} 
in their attempts to curry the emperor's favour by showing their participation in and enthusiasm for his successes, his rise to power, or the birth of an heir, and by constantly mentioning their goodwill, zeal, and devotion, and especially their loyalty. The emperors' replies tend to employ a similarly recurring terminology which presents the imperial figure as caring and protective towards the cities.

While the available evidence does not provide a definitive answer to the scholarly debate on the issue, the pattern followed by the interaction between the emperor and the cities could be applied to a hypothetical model of the process of creation of the Panhellenion League. Specifically, the pattern followed by the koinon of the Achaeans, Boeotians, Locrians, Phocians, and Euboeans in order to obtain Caligula's ratification might also have found a place in Hadrian's time and for the foundation of the Panhellenion.

ROCÍO GORDILLO HERVÁS

rgorher@upo.es 